\title{
Angiotensin II receptor type 1 is upregulated in atrial tissue of patients with rheumatic valvular disease with atrial fibrillation
}

\author{
Hongliang Cong, MD, PhD, Ximing Li, MD, PhD, Lijun Ma, MD, Hua Jiang, MD, Yongmin Mao, and \\ Meilin Xu
}

Objective: The purpose of this study was to examine the changes in expression of angiotensin II receptor type $1 / 2$ in left or right atrial tissue from patients with rheumatic valvular disease with or without atrial fibrillation.

\begin{abstract}
Methods: Atrial tissue samples were obtained from 39 patients with rheumatic mitral valve disease during cardiac surgery. Among these patients, there were 25 with atrial fibrillation and 14 with sinus rhythm. The level of angiotensin II receptor type 1 or type 2 mRNA transcription was measured by means of a semiquantitative reverse transcription-polymerase chain reaction technique. Expression of angiotensin II receptor type 1 or type 2 protein was detected by means of immunohistochemistry assay and Western blot analysis.
\end{abstract}

\begin{abstract}
Results: The inner diameter of the left atrium was clearly enlarged in the atrial fibrillation group in comparison with that seen in the sinus rhythm group. The expression levels of both angiotensin II receptor type $1 \mathrm{mRNA}$ and protein in the left atrial tissue were significantly increased in the patients with atrial fibrillation compared with those seen in patients with sinus rhythm $(P<.05)$. Interestingly, the comparison of angiotensin II receptor type 2 expression levels in the left atrial tissue between these 2 groups is not statistically significant. In addition, the results of angiotensin II receptor type 1 or 2 expression in the right atrial tissue did not show any obvious change in the patients with atrial fibrillation versus those with sinus rhythm.

Conclusions: Expression of angiotensin II receptor type 1 but not type 2 is highly upregulated only in the left atrial tissue of patients with rheumatic valvular disease with atrial fibrillation. This suggests that there is a possible pathophysiologic role of the renin-angiotensin system in patients with atrial fibrillation and that a series of effects mediated by the activation of angiotensin II receptor type 1 in the left atrial tissue might be one of the molecular mechanisms involved in the process of atrial remodeling in atrial fibrillation. (J Thorac Cardiovasc Surg 2010;140:298-304)
\end{abstract}

Atrial fibrillation (AF) in clinical practice is the most common arrhythmia associated with increasing morbidity and mortality mainly caused by heart failure and stroke. Recent studies have shown that angiotensin-converting enzyme inhibitor (ACEI) or angiotensin receptor blocker (ARB) therapy was beneficial in the management of $\mathrm{AF}$ and that the renin-angiotensin system (RAS) was regulated in the process of AF. However, the profile of angiotensin II receptor expression in atria with fibrillation still remains controversial. ${ }^{1,2}$ Our current investigation sought to determine whether there exists a difference in expression levels between angiotensin II receptor type 1 (AT1-R) and angiotensin II receptor type 2 (AT2-R) in left atrial (LA) or right atrial (RA) tissue from patients with rheumatic valve disease with or without AF.

From the Department of Cardiology, Tianjin Chest Hospital, Tianjin, China.

Disclosures: None.

Sponsored by Fund of Tianjin Municipal Health Bureau (05KYZ56).

Hongliang Cong and Ximing Li contributed equally to this work.

Received for publication Feb 14, 2009; revisions received Oct 22, 2009; accepted for publication Oct 29, 2009; available ahead of print Jan 18, 2010.

Address for reprints: Hongliang Cong, MD, PhD, Department of Cardiology, Tianjin

Chest Hospital, Tianjin 300051, China (E-mail: HongliangCong@126.com).

$0022-5223 / \$ 36.00$

Copyright (c) 2010 by The American Association for Thoracic Surgery

doi:10.1016/j.jtcvs.2009.10.035

\section{MATERIALS AND METHODS Inclusion Criteria}

Patients with rheumatic valve disease with AF or sinus rhythm (SR) underwent cardiac surgery for heart valve replacement (AF group, $n=25$; $S R$ group, $\mathrm{n}=14$ ). Patients in the AF group had persistent AF lasting more than 6 months without paroxysmal and self-terminating episodes. There was no observed paroxysmal AF in the SR group. All patients provided informed consent for retrieval of cardiac biopsy samples. Procedures were carried out according to our institutional ethical guidelines and the Declaration of Helsinki. All patients who received ultrasonic cardiographic examination did not have a history of taking ACEIs or ARBs. LA or RA tissues were obtained from the left or right auricle during cardiac surgery. Each sample was divided into 2 parts, one of which was quickly transferred into liquid nitrogen and stored at $-80^{\circ} \mathrm{C}$, which prepared for both the assay of $A T 1 R$ or $A T 2 R$ mRNA expression by means of reverse transcription-polymerase chain reaction (RT-PCR) and analysis of protein levels by means of Western blotting. The rest of the sample was fixed with formalin for immunohistologic analysis.

\footnotetext{
RT-PCR

Total RNA was extracted from the frozen atrial tissue by using Trizol reagent (Sigma, St Louis, Mo). The concentration and purity of the RNA was determined by measuring the absorbance at 260 and $280 \mathrm{~nm}$. The optical density 260/280 ratio of each total RNA sample was approximately 2.0. The final concentration of total RNA was adjusted to $1 \mu \mathrm{g} / \mu \mathrm{L}$. Each cDNA template was reverse transcribed with the Reverse Transcription System kit (Promega, Madison, Wis). The following protocol is optimized to generate a first-strand cDNA template for RT-PCR reaction. First, $4 \mu \mathrm{L}$ of total RNA sample was mixed with $10.5 \mu \mathrm{L}$ of diethylpyrocarbonate
} 


$\begin{aligned} & \text { Abbreviations and Acronyms } \\ & \text { ACE }=\text { angiotensin-converting enzyme } \\ & \text { ACEI }=\text { angiotensin-converting } \\ & \text { enzyme inhibitor } \\ & \text { AF }=\text { atrial fibrillation } \\ & \text { ARB }=\text { angiotensin receptor blocker } \\ & \text { AT1-R }=\text { angiotensin II receptor type } 1 \\ & \text { AT2-R }=\text { angiotensin II receptor type } 2 \\ & \text { GAPDH }=\text { glyceraldehyde-3-phosphate } \\ & \text { LA } \text { dehydrogenase } \\ & \text { PBS } \text { left atrium } \\ & \text { PCR }=\text { phosphate-buffered saline } \\ & \text { RA }=\text { right atrium } \\ & \text { RAS }=\text { renin-angiotensin system } \\ & \text { RT-PCR } \text { reverse transcription-polymerase } \\ & \text { chain reaction } \\ & \text { SR }=\text { sinus rhythm }\end{aligned}$

$\mathrm{H}_{2} \mathrm{O}$, and $0.5 \mu \mathrm{L}$ of oligo dT-adaptor primer was incubated at $70^{\circ} \mathrm{C}$ for 5 minutes. Second, after 5 minutes, the mixture was supplemented with 4 $\mu \mathrm{L}$ of diethylpyrocarbonate $\mathrm{H}_{2} \mathrm{O}, 6 \mu \mathrm{L}$ of $5 \times$ RNA polymerase chain reaction (PCR) buffer, $3 \mu \mathrm{L}$ of deoxyribonucleoside triphosphate (10 $\mathrm{mmol} / \mathrm{L}), 0.7 \mu \mathrm{L}$ of RNase inhibitor, and $1.3 \mu \mathrm{L}$ of M-MLV and was again incubated at $37^{\circ} \mathrm{C}$ for 1 hour. $A T 1 R$ and $A T 2 R$ gene expression was analyzed by means of RT-PCR. The specific primers used in this study (Table 1) were designed by Shanghai Sang Gong Company. Expression of glyceraldehyde3-phosphate dehydrogenase (GAPDH) mRNA was used as an internal control. PCR was performed in a total volume of $25 \mu \mathrm{L}$ for each reaction, which included $1 \mu \mathrm{L}$ of the first-strand cDNA synthesis mixture, $5 \mu \mathrm{L}$ of $5 \times$ PCR Buffer, $0.25 \mu \mathrm{L}$ of Taq DNA Polymerase, $0.5 \mu \mathrm{L}$ of the respective target gene primer $(20 \mu \mathrm{mol} / \mathrm{L})$, or $0.1 \mu \mathrm{L}$ of $G A P D H$ primer $(20 \mu \mathrm{mol} / \mathrm{L})$. The PCR reaction was programmed as follows. First, initial denaturation was performed at $94^{\circ} \mathrm{C}$ for 5 minutes. Second, the samples were subjected to 35 cycles, including denaturation at $94^{\circ} \mathrm{C}$ for 30 seconds, primer annealing at $58^{\circ} \mathrm{C}$ (AT1-R) or $60^{\circ} \mathrm{C}$ (AT2-R) for 30 seconds, and extension at $72^{\circ} \mathrm{C}$ for 60 seconds. At the end of 35 cycles, the samples were kept at $72^{\circ} \mathrm{C}$ for extension for 7 minutes. After PCR amplification, $10 \mu \mathrm{L}$ of PCR product from each sample was electrophoresed through a $2 \%$ agarose gel, and amplified bands were detected by means of ethidium bromide staining. The relative amount of angiotensin II receptors in each sample was investigated by comparison of gray scale values of target genes with the gray scale signal of $G A P D H$. The GAPDH value was used as an adjusting factor to ensure that the same amount of cellular genes in each patient was determined. The ratio of angiotensin II receptor/GAPDH from each patient was used to calculate possible differences in expression of angiotensin II receptors (Table 2).

\section{Immunohistochemistry}

Immunohistochemical detection of AT1-R or AT2-R expression was performed on 5- $\mu \mathrm{m}$ transverse paraffin sections. Sections were deparaffinized with xylene, placed in $100 \%$ ethanol, and then rehydrated through graded ethanol solutions. Endogenous peroxidase activity was quenched by means of incubation with $3 \%$ hydrogen peroxide in phosphate-buffered saline (PBS). Antigen retrieval was accomplished by microwaving sections in citrate buffer ( $\mathrm{pH}$ 6.0). Then the sections were washed with PBS ( $\mathrm{pH} 7.0$ ). The sections were incubated with $30 \mu \mathrm{L}$ of primary antibody (rabbit antiAT1-R or anti-AT2-R receptor polyclonal antibody, 1:50) at $37^{\circ} \mathrm{C}$ for 1 hour. After primary antibody incubation, the sections were washed with PBS 3 times (for 5 minutes each) and then incubated with secondary antibody at $37^{\circ} \mathrm{C}$ for 20 minutes. At the end, these sections were counterstained with hematoxylin and mounted. We used Image-Pro Plus 5.02 (Media Cybernetics, Inc, Bethesda, Md) to calculate the integrated optical density to quantitate the AT1-R or AT2-R protein expression (Table 3).

\section{Western Blot Analysis}

To determine whether there exists a difference between the SR and AF groups in LA or RA tissue's AT1-R or AT2-R protein levels, Western blotting was performed on tissue homogenates of LA or RA $(70 \mathrm{mg})$. Briefly, total homogenate was prepared by using a triple-detergent lysis buffer with the protease inhibitors phenylmethylsulfonyl fluoride and aprotinin. One hundred fifty microliters of homogenate was mixed with $50 \mu \mathrm{L}$ of loading buffer $(1: 4)$ and heated to $100^{\circ} \mathrm{C}$ for 5 minutes, and $30 \mu \mathrm{L}$ of the prepared sample was then loaded into each lane. Protein was resolved on a $7.5 \%$ acrylamide trisglycine gel and blotted onto a polyvinylidene difluoride membrane and then detected with rabbit anti-AT1-R or rabbit antiAT2-R (BOSTER; dilution 1:100) and horseradish peroxidase-conjugated secondary antibody with chemiluminescent substrate. $\alpha$-Tubulin was used as an internal control. The relative amount of angiotensin II receptors in each sample was investigated by means of comparison of gray scale values of target protein with the gray scale signal of $\alpha$-tubulin. The $\alpha$-tubulin value was used as an adjusting factor to assure that the same amount of cellular protein in each patient was determined. The ratio of angiotensin II receptor $/ \alpha$-tubulin from each patient was used to calculate possible differences in expression of angiotensin II receptors (Table 4 and Figure 1).

\section{Data Analysis}

Data are presented as means \pm standard errors, which were compared by using independent-samples $t$ tests.

\section{RESULTS \\ Patients}

The baseline data of the patients are summarized in Table 5 . Compared with the SR group, the inner diameter of the

TABLE 1. PCR information for AT1R, AT2R, and GAPDH genes

\begin{tabular}{llcc}
\hline Target genes & \multicolumn{1}{c}{ Primer } & Length (bp) & Annealing temperature $\left({ }^{\circ} \mathbf{C}\right)$ \\
\hline$A T 1 R$ & Upper: 5'-GATGATTGTCCCAAAGCTGG-3' & 256 & 58 \\
& Lower: 5'-TAGGTAATTGCCAAAGGGCC-3' & & \\
AT2R & Upper: 5'-GGGCTTGTGAACATCTCTGG-3' & 214 & 60 \\
& Lower: 5'-GTAAATCAGCCACAGCGAGG-3' & & \\
GAPDH & Upper: 5'-TCCATGACAACTTTGGCATCGTGG -3' & & Changing \\
& Lower: 5'-GTTGCTGTTGAAGTCACAGGAGAC-3' & & \\
\hline
\end{tabular}

$P C R$, Polymerase chain reaction; $A T 1-R$, angiotensin II receptor type 1; $A T 2-R$, angiotensin II receptor type 2; GAPDH, glyceraldehyde-3-phosphate dehydrogenase. 
TABLE 2. The comparison of AT-R subtype mRNA expression between the AF and SR groups

\begin{tabular}{lcclcc}
\hline & \multicolumn{2}{c}{ AT1R } & & \multicolumn{2}{c}{ AT2R } \\
\cline { 2 - 3 } \cline { 5 - 6 } Group & RA & LA & & RA & LA \\
\hline $\mathrm{AF}$ & $1.667 \pm 0.209$ & $1.736 \pm 0.170$ & & $2.043 \pm 0.629$ & $1.593 \pm 0.283$ \\
$\mathrm{SR}$ & $1.766 \pm 0.379$ & $1.507 \pm 0.346$ & & $1.842 \pm 0.583$ & $1.573 \pm 0.306$ \\
$P$ value & .36 & .028 & & .317 & .833 \\
\hline
\end{tabular}

$A T-R$, Angiotensin II receptor; $A F$, atrial fibrillation; $S R$, sinus rhythm; $A T 1-R$, angiotensin II receptor type 1; $A T 2-R$, angiotensin II receptor type 2; $R A$, right atrium; $L A$, left atrium.

LA was significantly increased in patients of the AF group. However, there were no significant differences in the inner diameter between the left and right ventricles or the RAs in left ventricular ejection fraction and pulmonary arterial pressure between the 2 groups. However, the patients in the AF group had a slightly higher pulmonary artery pressure than the patients in SR.

\section{RT-PCR Results}

The level of $A T I R$ mRNA expression in the LA was highly increased in patients with AF compared with that seen in those with SR $(P=.028)$, whereas the change in $A T 2 R$ mRNA expression in the LA was not statistically significant $(P=.36$, Figure 2$)$. The data of angiotensin II receptor subtypes' mRNA levels in the RA did not exhibit any obvious changes either in $A T 1 R$ or $A T 2 R$ expression in patients with AF versus those with SR (Table 2).

\section{Immunohistochemistry Results}

AT2-R protein expression in LA or RA tissue detected by means of immunohistochemical staining showed no difference between the AF and SR groups (Figure 3). Expression of AT2-R protein was not comparable between the patients with AF and those with SR (LA: AF vs SR, $P=.79$; RA: AF vs RA, $P=.15$ ). The AT1-R protein expression in the LA was higher in patients of the AF group (Figure 4,C) compared with that seen in patients in the SR group $(P=.01$; Figure $4, D$ ), but there is no significant difference for AT1-R protein expression in the RA between the 2 groups $(P=.77)$.

\section{Western Blot Analysis Results}

AT2-R protein expression in LA or RA tissue analyzed by means of Western blotting showed no difference between the AF and SR groups (Figure 5, A, and Figure 1; LA: AF vs SR, $P=.75$; RA: AF vs RA, $P=.06$ ). The AT1-R protein expression in the LAs of the AF group was higher than that in the LAs of the SR group (Figure 5, $B$, and Figure $1 ; P=.02$ ), but there is no significant difference in AT1-R protein expression in RAs between the 2 groups $(P=.33)$.
TABLE 3. The calculated IOD of AT-1R or AT2-R protein in the AF and SR groups $\left(\times 10^{3}\right)$

\begin{tabular}{lccccc}
\hline & \multicolumn{2}{c}{ AT1-R } & & \multicolumn{2}{c}{ AT2-R } \\
\cline { 2 - 3 } \cline { 5 - 6 } Group & RA & LA & & RA & LA \\
\hline $\mathrm{AF}$ & $47.30 \pm 14.85$ & $69.17 \pm 15.52 *$ & $82.54 \pm 11.60$ & $79.92 \pm 8.52$ \\
$\mathrm{SR}$ & $45.91 \pm 13.59$ & $56.64 \pm 11.76$ & & $88.79 \pm 14.92$ & $80.73 \pm 26.07$ \\
$P$ value & .771 & .011 & & .152 & .79 \\
\hline
\end{tabular}

$I O D$, Integrated optical density; $A T 1-R$, angiotensin II receptor type $1 ; A T 2-R$, angiotensin II receptor type 2; $A F$, atrial fibrillation; $S R$, sinus rhythm; $R A$, right atrium; $L A$, left atrium.

\section{DISCUSSION}

It has been well documented that AF can cause atrial remodeling, which can promote $\mathrm{AF}$ initiation and maintenance. $^{3-5}$ There are 2 types of atrial remodeling: structural remodeling and electrical remodeling. Structural remodeling includes significant changes in atrial tissue, such as accumulation of increased amounts of fibrous tissue and collagen. Electrical remodeling refers to any change in electrophysiologic function that promotes AF initiation and maintenance. The RAS is one of the most important neuroendocrine systems in the organism and plays an important role in adjusting the homeostasis of fluid balance and the cardiovascular system. Its overactivation during $\mathrm{AF}$ has been well known. Serum aldosterone levels have been shown to decrease in patients with $\mathrm{AF}$ after restoration of SR, which reflects the activation of the RAS in patients with AF. ${ }^{6}$ Goette and colleagues ${ }^{7}$ measured the activity of angiotensin-converting enzyme (ACE) in human atrial appendages from patients with AF or SR undergoing cardiac surgery and found a 3-fold increase in ACE activity in patients with permanent AF compared with that seen in those with SR. AF leads to RAS activation, which seems to play a critical role in atrial electrical and structural remodeling. Angiotensin II, as the most important hormone of the RAS, is involved in the regulation of cardiovascular function through expression of its type 1 and type 2 receptors. We found significant upregulation of AT1-R in LA tissue of the AF group compared with that seen in the SR group. Interestingly, there is no significant difference in AT2-R expression in the LA tissue between the 2 groups. Therefore we believe that the AT1-R upregulation might be necessary for the process of atrial

TABLE 4. The comparison of AT-R subtype protein expression between the $\mathrm{AF}$ and $\mathrm{SR}$ groups

\begin{tabular}{lcclcc}
\hline & \multicolumn{2}{c}{ AT1-R } & & \multicolumn{2}{c}{ AT2-R } \\
\cline { 2 - 3 } \cline { 5 - 6 } Group & RA & LA & & RA & LA \\
\hline AF & $0.222 \pm 0.046$ & $0.274 \pm 0.062 *$ & & $0.297 \pm 0.057$ & $0.271 \pm 0.064$ \\
SR & $0.206 \pm 0.055$ & $0.226 \pm 0.052$ & & $0.334 \pm 0.060$ & $0.265 \pm 0.043$ \\
$P$ value & .326 & .021 & & .064 & .754 \\
\hline
\end{tabular}

$A T-R$, Angiotensin II receptor; $A F$, atrial fibrillation; $S R$, sinus rhythm; $A T 1-R$, angiotensin II receptor type 1; $A T 2-R$, angiotensin II receptor type 2; $R A$, right atrium; $L A$, left atrium. 

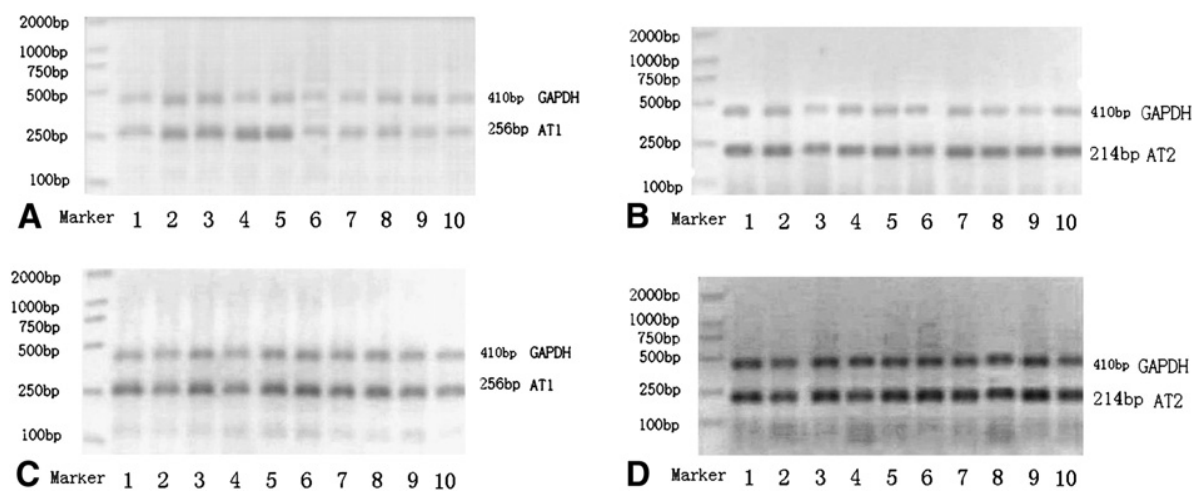

FIGURE 1. Bar graph for Western blot analysis results. $L A$, Left atrium; $R A$, right atrium; $A F$, atrial fibrillation; $S R$, sinus rhythm; $A n g I I$, angiotensin II; $A T I$, angiotensin II receptor type 1; AT2, angiotensin II receptor type 2.

remodeling and plays a pivotal role in the initiation and aggravation of AF. The cascade reactions activated by angiotensin II through AT1-R can result in increasing expression of cell-cycle and cytokine-regulating genes. The latter can induce the activity of mitogenic signaling pathways, such as mitogen-activated protein kinase and Janus kinase/signal transducer and activator of transcription, which can ultimately lead to activation of transcription factors controlling the expression of structural and cell-cycle regulatory proteins and cause fibroblast proliferation, extracellular matrix deposition, apoptotic changes, and intracellular communication alterations. ${ }^{8,9}$ Atrial fibrosis is probably the most critical component of the remodeling process in patients with AF. ${ }^{10,11}$ The fibrosis is characterized by a marked slowing in cardiac impulse propagation that might favor reentrant circuits in "microregions" where AF might persist, which is considered to be an irreversible role in the progression of these pathophysiologic changes with $\mathrm{AF}$, especially persistent AF. Moexipril or enalaprilat, an ACEI, can inhibit proliferation of cardiac fibroblasts induced by angiotensin II according to their relative potency of ACE inhibition in vitro. ${ }^{9}$ Recently, there is increasing evidence that blocking the RAS with ACEIs or ARBs has a positive role in preventing new onset of AF and maintaining SR in patients with recurrent AF. ${ }^{12,13}$ In the Losartan Intervention for End-point Reduction in Hypertension trial, ${ }^{14}$ the use of the ARB losartan resulted in fewer cases of new-onset AF. For patients with AF with left ventricular hypertrophy, losartan-based therapy resulted in fewer strokes and cardiovascular events. ${ }^{15}$ A post hoc ancillary analysis from a large random- ized trial of anticoagulation has demonstrated a significant benefit of ACEI or ARB use among elderly patients with AF. Patients aged 75 years taking ACEIs or ARBs had lower mortality. ${ }^{16}$ However, there is also clinical evidence showing that pretreatment with ACEIs does not prevent AF recurrences and might only improve acute success of electrical cardioversion. ${ }^{17}$ However, meta-analysis confirms that ACEIs and ARBs appeared to be very effective in the prevention of AF, especially in patients with systolic left ventricular dysfunction or left ventricular hypertrophy. ${ }^{18}$ The benefits of ACEIs and ARBs in the treatment of AF might be attributed to their antiremodeling effects. ${ }^{19,20}$ Boldt and associates $^{21}$ found that there was a significantly lower expression of collagen I in patients with chronic AF with ACEI treatment and that the microcapillaries were significantly rare in cases of AF without ACEIs. Therefore ACEI treatment can attenuate atrial structural remodeling and prevent the loss of atrial microcapillaries. In addition, a recent animal experiment proved that both cilazapril and valsartan can inhibit calpain I upregulation, suppress atrial structural remodeling, and prevent the induction and promotion of $\mathrm{AF}$ in dogs undergoing persistent rapid atrial pacing. ${ }^{22} \mathrm{De}-$ spite much progress in the study of the molecular mechanism of AF treatment with ACEIs or ARBs, the definite signaling network of AF pathogenesis remains to be further investigated.

In contrast to our study, it has been reported by Goette and colleagues, ${ }^{1}$ who studied the regulation of angiotensin II receptor subtypes in patients with $\mathrm{AF}$, that expression of type 1 receptor was downregulated. However, our findings are

TABLE 5. Clinical characteristics of patients in the AF and SR groups

\begin{tabular}{|c|c|c|c|c|c|c|c|c|c|c|}
\hline & \multirow[b]{2}{*}{ Male (n) } & \multirow[b]{2}{*}{ Female (n) } & \multirow[b]{2}{*}{ Age (y) } & \multirow[b]{2}{*}{ LAD $(\mathbf{m m})$} & \multirow[b]{2}{*}{$\operatorname{RAD}(\mathbf{m m})$} & \multirow[b]{2}{*}{ LVD (mm) } & \multirow[b]{2}{*}{ EF $(\%)$} & \multirow[b]{2}{*}{ PA (mm Hg) } & \multicolumn{2}{|c|}{ Valve disease } \\
\hline & & & & & & & & & MS & $\mathbf{M S}+\mathbf{M I}$ \\
\hline $\mathrm{AF}$ & 6 & 18 & $53.88 \pm 9.83$ & $58.58 \pm 7.91^{*}$ & $42.29 \pm 6.96$ & $48.29 \pm 7.07$ & $61.37 \pm 8.17$ & $54.08 \pm 12.5$ & 15 & 9 \\
\hline SR & 4 & 11 & $48.27 \pm 10.37$ & $48.67 \pm 5.39$ & $39.26 \pm 5.79$ & $49.06 \pm 8.46$ & $58.93 \pm 7.12$ & $47.8 \pm 14.80$ & 9 & 6 \\
\hline
\end{tabular}

$A F$, Atrial fibrillation; $S R$, sinus rhythm; $L A D$, left atrial inner diameter; $R A D$, right atrial inner diameter; $L V D$, left ventricular inner diameter; $E F$, ejection fraction; $P A$, pulmonary artery systolic pressure; $M S$, mitral stenosis; $M I$, mitral regurgitation. *Compared with the SR group: $P<.05$. 

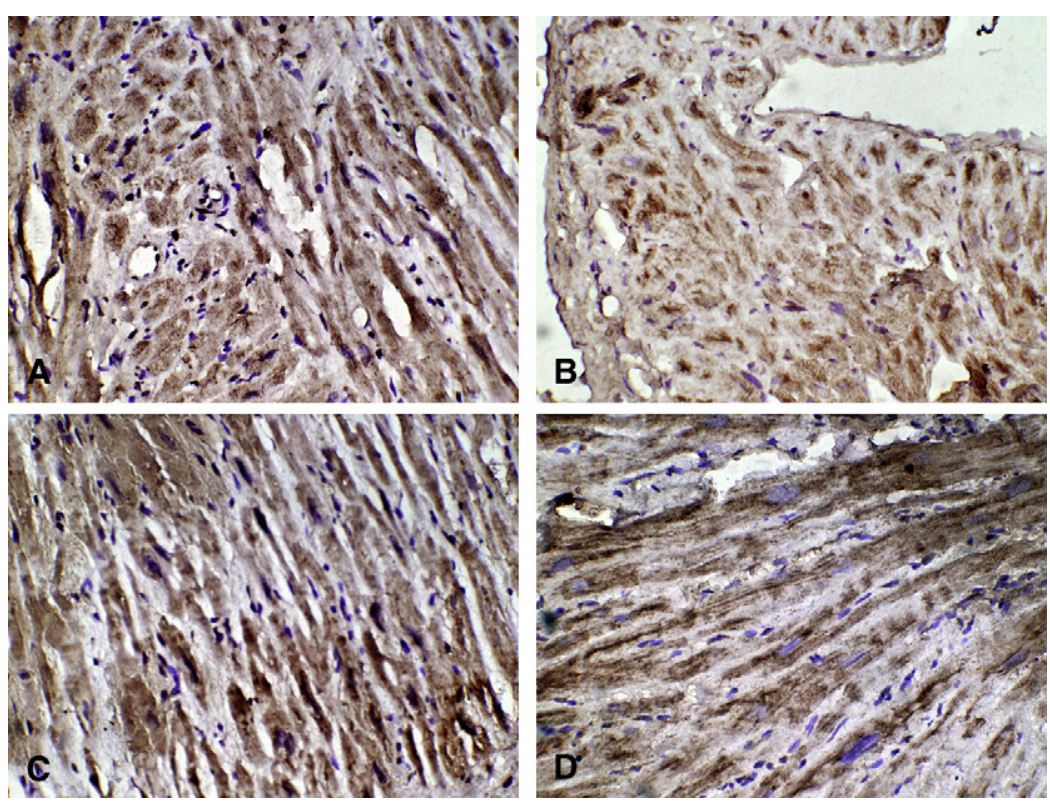

FIGURE 2. Reverse transcription-polymerase chain reaction results. A and B, Left atrium; C and D, right atrium; 1-5, atrial fibrillation group; 6-10, sinus rhythm group. GAPDH, Glyceraldehyde-3-phosphate dehydrogenase; AT1, angiotensin II receptor type 1; AT2, angiotensin II receptor type 2.

partially supported by data from Boldt and coworkers ${ }^{2}$ that expression of AT1-R receptors in LA tissue was highly increased in patients with lone AF or AF caused by mitral valve disease. The difference in these studies might be caused by the variation of the enrolled patient population. Our data suggest that upregulation of AT1-R in LA tissue of patients with $\mathrm{AF}$ could be one of the molecular bases in the process of atrial structural remodeling. Further studies are needed to distinguish the difference and changes of angiotensin II receptor subtype expression in $\mathrm{AF}$ of different causes.

Taken together, many other lines of evidence have increasingly indicated that angiotensin II might play a determinant role in conditioning structural remodeling during $\mathrm{AF}$.

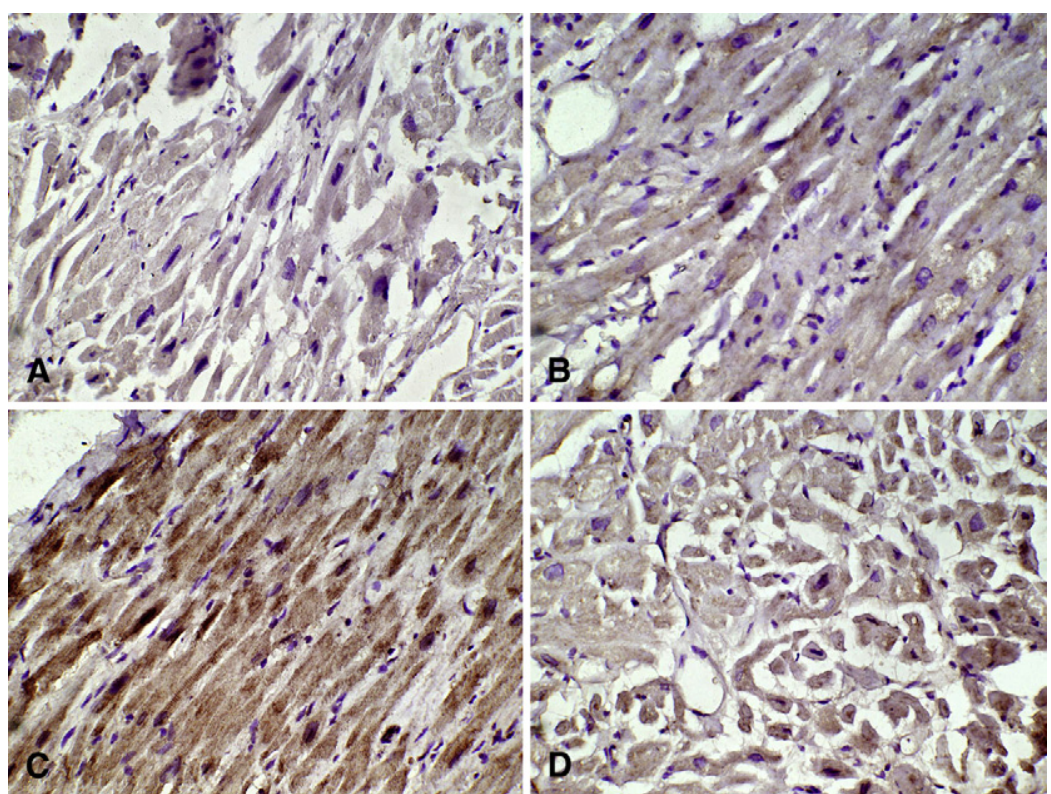

FIGURE 3. Expression of angiotensin II receptor type 2 in the left or right atrial tissues of the atrial fibrillation (AF) or sinus rhythm (SR) groups. A, Right atrial tissue of the AF group; B, right atrial tissue of the SR group, group; C, left atrial tissue of the AF group; D, left atrial tissue of the SR group. (Original magnification $10 \times 20$.) 


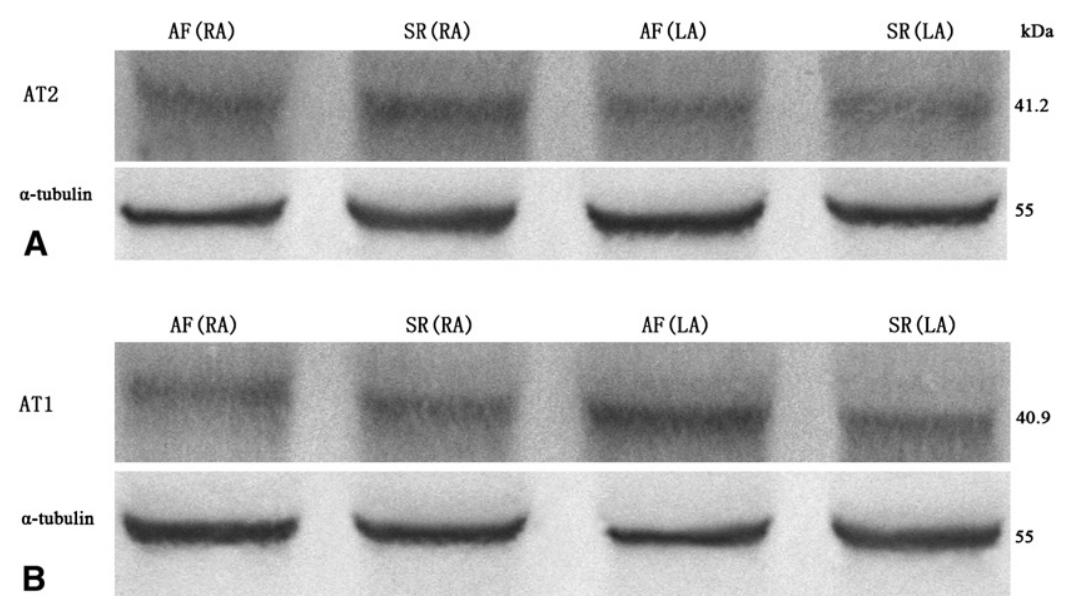

FIGURE 4. Expression of angiotensin II receptor type 1 in left or right atrial tissues of the atrial fibrillation (AF) and sinus rhythm (SR) groups. A, Right atrial tissue of the AF group; B, right atrial tissue of the SR group; C, left atrial tissue of the AF group; D, left atrial tissue of the SR group. (Original magnification 10 $\times 20$ ). Angiotensin II receptor type 1 is strongly expressed in left atria of the AF group.

Although inhibitors of the RAS cannot be considered antiarrhythmic drugs from a conventional viewpoint, their capability of reducing ventricular arrhythmias and sudden cardiac death in patients with previous myocardial infarction and heart failure has long been recognized. Both experimental and clinical data have confirmed the proarrhythmic role of the RAS and demonstrated an antiarrhythmic effect of ACEIs and AT1-R receptor blockers. ${ }^{15,23}$

Our current study has demonstrated that the expression of AT1-R mRNA and protein in the LAs of patients with AF

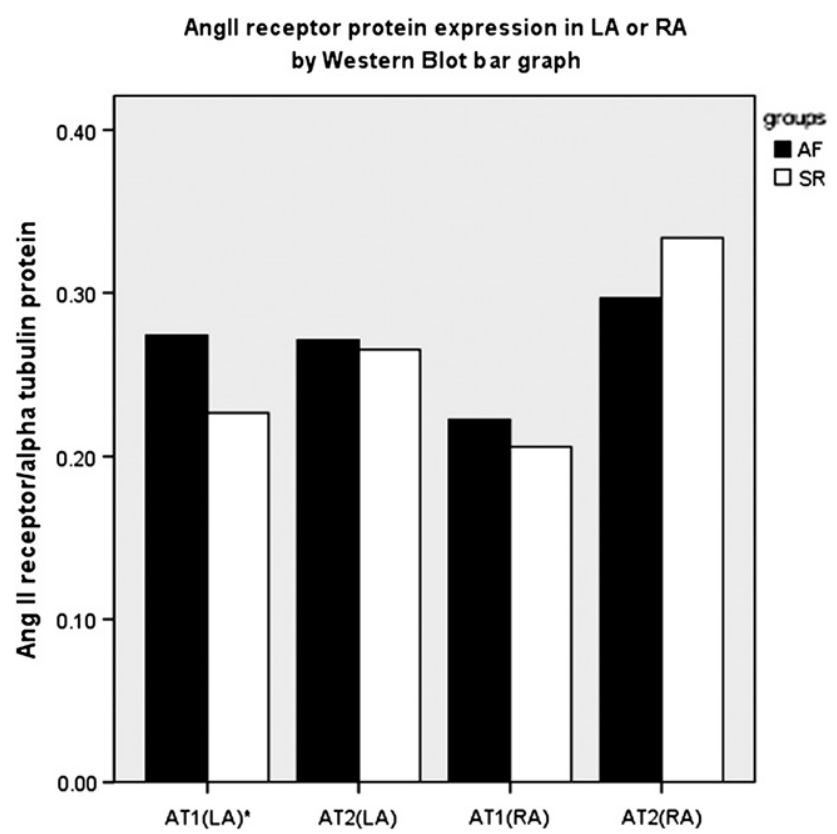

FIGURE 5. A, Protein expression of angiotensin II receptor type 2 (AT2) in the left $(L A)$ or right atrial $(R A)$ tissues of the atrial fibrillation $(A F)$ or sinus rhythm $(S R)$ groups. B, Protein expression of angiotensin II receptor type 1 (AT1) in the LA or RA tissues of the AF or SR groups. caused by rheumatic valve disease is significantly increased. This might indicate that there is a possible pathophysiologic role for the RAS in AF. A series of effects mediated by the activation of AT1-R might be one of the molecular mechanisms involved in the process of atrial remodeling in AF. In any case, the dissection of hierarchic signaling pathways in atrial remodeling of AF needs to be further pursued.

This was a single-center observational clinical study on $\mathrm{AF}$ caused by rheumatic valve disease. Rheumatic valve disease is the most common cause of AF. All the patients enrolled in this study had serious rheumatic valvular damage, which could contribute to atrial remodeling. However, in other forms of $\mathrm{AF}$, such as $\mathrm{AF}$ without rheumatic valvular disease or with other heart structural defects, the related mechanisms of initiation, persistence, and recurrence in these cases of $\mathrm{AF}$ remain to be investigated in future studies.

\section{References}

1. Goette A, Arndt M, Röcken C, Spiess A, Staack T, Geller JC, et al. Regulation of angiotensin II receptor subtypes during atrial fibrillation in humans. Circulation. 2000;101:2678-81

2. Boldt A, Wetzel U, Weigl J, Garbade J, Lauschke J, Hindricks G, et al. Expression of angiotensin II receptors in human left and right atrial tissue in atrial fibrillation with and without underlying mitral valve disease. J Am Coll Cardiol. 2003;42: 1785-92.

3. Wijffels MCEF, Kirchhof CJHJ, Dorland R, Allessie MA. Atrial fibrillation begets atrial fibrillation. A study in awake chronically instrumented goats. $\mathrm{Circu}$ lation. 1995;92:1954-68.

4. Anyukhovsky EP, Sosunov EA, Chandra P, Rosen TS, Boyden PA, Danilo P, et al. Age-associated changes in electrophysiologic remodeling: a potential contributor to initiation of atrial fibrillation. Cardiovasc Res. 2005;66:353-63.

5. Pandit SV, Berenfeld O, Anumonwo JMB, Zaritski RM, Kneller J, Nattel A, et al. Ionic determinants of functional reentry in a 2-D model of human atrial cells during simulated chronic atrial fibrillation. Biophys J. 2005;88:3806-21.

6. Goette A, Hoffmanns P, Enayati W, Meltendorf U, Geller JC, Klein HU. Effect of successful electrical cardioversion on serum aldosterone in patients with persistent atrial fibrillation. Am J Cardiol. 2001;88:906-9.

7. Goett A, Staack T, Röcken C, Arndt M, Geller JC, Huth C, et al. Increased expression of extracellular signal-regulated kinase and angiotensin-converting enzyme in human atria during atrial fibrillation. J Am Coll Cardiol. 2000;35: 1669-77. 
8. Sugden PH, Clerk A. Regulation of the ERK subgroup of MAP kinase cascades through G protein-coupled receptors. Cell Signal. 1997;9:337-51.

9. van Eickels M, Grohé C, Löbbert K, Stimpel M, Vetter H. Angiotensin converting enzyme inhibitors block mitogenic signalling pathways in rat cardiac fibroblasts. Naunyn Schmiedebergs Arch Pharmacol. 1999;359:394-9.

10. Goette A, Juenemann G, Peters B, Klein HU, Roessner A, Huth C, et al. Determinants and consequences of atrial fibrosis in patients undergoing open heart surgery. Cardiovasc Res. 2002;54:390-6.

11. Sakabe K, Fukuda N, Nada T, Shinohara H, Tamura Y, Wakatsuki T. Age-related changes in the electrophysiologic properties of the atrium in patients with no history of atrial fibrillation. Jpn Heart J. 2003;44:385-93.

12. Ueng K-C, Tsai T-P, Yu W-C, Tsai C-F, Lin M-C, Chan K- C, et al. Use of enalapril to facilitate sinus rhythm maintenance after external cardioversion of longstanding persistent atrial fibrillation: results of a prospective and controlled study. Eur Heart J. 2003;24:2090-8.

13. Madrid AH, Bueno MG, Rebollo JMG, Marín I, Peña G, Bernal E, et al. Use of irbesartan to maintain sinus rhythm in patients with long-lasting persistent atrial fibrillation: a prospective and randomized study. Circulation. 2002;106:331-6.

14. Wachtell K, Lehto M, Gerdts E, Olsen MH, Hornestam B, Dahlöf B, et al. Angiotensin II receptor blockade reduces new-onset atrial fibrillation and subsequent stroke compared to atenolol: the Losartan Intervention For End Point Reduction in Hypertension (LIFE) study. J Am Coll Cardiol. 2005;45:712-9.

15. Wachtell K, Hornestam B, Lehto M, Slotwiner DJ, Gerdts E, Olsen MH, et al. Cardiovascular morbidity and mortality in hypertensive patients with a history of atrial fibrillation: the Losartan Intervention For End Point Reduction in Hypertension (LIFE) study. J Am Coll Cardiol. 2005;45:705-11.
16. Lip GY, Frison L, Grind M. Angiotensin converting enzyme inhibitor and angiotensin receptor blockade use in relation to outcomes in anticoagulated patients with atrial fibrillation. J Intern Med. 2007;261:577-86.

17. Van Noord T, Crijns HJGM, van den Berg MP, Van Veldhuisen DJ, Van Gelder IC. Pretreatment with ACE inhibitors improves acute outcome of electrical cardioversion in patients with persistent atrial fibrillation. BMC Cardiovasc Disord. 2005;5:3.

18. Healey JS, Baranchuk A, Crystal E, Morillo CA, Garfinkle M, Yusuf S, et al. Prevention of atrial fibrillation with angiotensin-converting enzyme inhibitors and angiotensin receptor blockers: a meta-analysis. J Am Coll Cardiol. 2005;45:1832-9.

19. Boos CJ, Lip GY. Targeting the renin-angiotensin-aldosterone system in atrial fibrillation: from pathophysiology to clinical trials. J Hum Hypertens. 2005;19: $855-9$.

20. Nakashima H, Kumagai K, Urata H, Gondo N, Ideishi M, Arakawa K, et al. Angiotensin II antagonist prevents electrical remodeling in atrial fibrillation. Circulation. 2000;101:2612-7.

21. Boldt A, Scholl A, Garbade J, Resetar ME, Mohr FW, Gummert JF, et al. ACEinhibitor treatment attenuates atrial structural remodeling in patients with lone chronic atrial fibrillation. Basic Res Cardiol. 2006;101:261-7.

22. Li Y, Li W-M, Gong Y-T, Li B-X, Liu W, Han W, et al. The effects of cilazapril and valsartan on the mRNA and protein expressions of atrial calpains and atrial structural remodeling in atrial fibrillation dogs. Basic Res Cardiol. 2007;102:245-56.

23. Li D, Shinagawa K, Pang L, Leung TK, Cardin S, Wang Z, et al. Effects of angiotensin-converting enzyme inhibition on the development of the atrial fibrillation substrate in dogs with ventricular tachypacing-induced congestive heart failure. Circulation. 2001;104:2608-14. 